\title{
Low- and reduced-fat milled curd, direct-salted Gouda cheese: Comparison of lactose standardization of cheesemilk and whey dilution techniques
}

\author{
R. A. Ibáñez, ${ }^{1,2} \odot$ S. Govindasamy-Lucey, ${ }^{2 *} \odot$ J. J. Jaeggi, ${ }^{2}$ M. E. Johnson, ${ }^{2} \oplus$ P. L. H. McSweeney, ${ }^{1}$ \\ and J. A. Lucey ${ }^{2}$ (D) \\ ${ }^{1}$ School of Food and Nutritional Sciences, University College Cork, T12 Y337, Ireland \\ ${ }^{2}$ Center for Dairy Research, University of Wisconsin-Madison, 53706
}

\begin{abstract}
Control of acidity is critical for cheese quality, as high acidity can be associated with poor flavor and textural attributes. We investigated an alternative method to control cheese acidity, specifically in low-fat (LF) and reduced-fat (RF) milled curd, direct-salted Gouda cheese, which involved altering the initial lactose content of cheesemilk. In traditional Gouda cheese manufacture, a critical technique to control acidity is whey dilution (WD); that is, partial removal of whey and its replacement with water. Direct standardization of the lactose content of milk during the ultrafiltration process could be a simpler and more effective technique to control cheese acidity. This study compared the effect of traditional WD at 2 different levels, 15 and $30 \%$ (WD15 and WD30), with the alternative approach of adjustment of the lactose content of milk using lowconcentration-factor ultrafiltration (LCF-UF). The composition, texture, functionality, and sensory properties of these LF and RF Gouda cheeses were evaluated. A milled curd, direct-salted cheese manufacturing protocol was used. Milks used for cheesemaking had a lactose-to-casein (L:CN) ratio of approximately 1.8, which is the typical ratio found in milk, whereas milks prepared with lactose standardization (LS) were made from UF concentrated milks with water added during filtration to achieve a $\mathrm{L}: \mathrm{CN}$ ratio of approximately 1.1. Cheeses made with LS exhibited lower lactose and lactic acid contents than WD30 and WD15, leading to significantly higher $\mathrm{pH}$ values in the cheese. Dynamic small-amplitude oscillatory rheology indicated that use of LS led to cheeses with a lower crossover temperature (melting point) than the cheeses made with WD. Cheeses made with LS had lower insoluble Ca contents, likely caused by the addition of water required to achieve the
\end{abstract}

Received July 18, 2019.

Accepted October 20, 2019

*Corresponding author rani@cdr.wisc.edu lower L:CN ratio in these milks. Sensory analysis also indicated that LS cheeses had lower acidity and softer texture. These results suggest that standardization of the L:CN ratio of milk could be a useful alternative to WD (or a curd rinse step) to reduce acidity in cheeses. In addition, LS could be used to help soften texture and increase meltability, if desired in lower-fat cheese types. Key words: low-concentration-factor ultrafiltration, lactose-to-casein ratio, cheese acidity, low-fat cheese

\section{INTRODUCTION}

Excessive acidity is one of the most common flavor defects and the cause for textural defects in many varieties of cheese. Cheeses with high moisture content are especially prone to this defect because the lactose content in curd increases with increasing moisture content. Lactose fermentation by the starters continues in cheese until the lactose is completely fermented or until environmental conditions within the cheese, such as low temperature or high salt, inhibit starter metabolism. The most reliable method to prevent excessive acidity in cheese is to reduce the lactose content in the curd before hooping. This can be accomplished through several methods. In the manufacture of Colby (Lee et al., 2011) and direct-salted Gouda, a curd rinse with cool water is generally used. Cooling the curd also helps to increase moisture content but can lead to high salt losses if the curd is pressed too soon after salting. In the manufacture of Swiss, warm water is sometimes added directly to the milk (up to 5 to $7 \%$ of the milk weight). In the manufacture of Gouda and Edam (Van den Berg et al., 2004), Havarti, Baby Swiss, and Brick cheese, whey is partially removed and water is added to the remaining curd and whey. The amount of whey removed (approx. 25 to 35\%) and the amount of water added (approx. 15 to 30\%) is based on the experience of the cheesemaker, the milk composition (CN and lactose contents), and the desired acidity of the cheese. Several studies have investigated the effect of whey dilution (WD) on cheese properties. Rehman 
et al. (2004) used 25\% WD (as a percentage of the total volume of curd and whey) to reduce levels of lactose to compare its effect on Cheddar-style cheeses made from milks containing regular $(4.2 \%)$ and high $(8.4 \%)$ lactose contents. The authors found that modifying the lactose content of cheese had little or no effect on the gross and chemical composition, primary proteolysis, or numbers of starter and non-starter lactic acid bacteria. Cheese made from high-lactose milk exhibited lower $\mathrm{pH}$ values, and sensory analysis indicated that it was more acidic. In contrast, cheese made with WD (low lactose) had lower acidity and was less firm. In a recent study, Hou et al. (2014) increased levels of WD from 0 to $33 \%$ (as a percentage of milk volume) with warm water $\left(38^{\circ} \mathrm{C}\right)$ in the manufacture of Cheddar cheese to reduce the levels of lactose and lactic acid. An increase in levels of WD led to cheeses with similar composition and primary proteolysis but higher $\mathrm{pH}$ values and firmer texture. Sensory analysis also showed that increasing levels of WD led to cheeses with lower acidity and the development of different flavor profiles (Hou et al., 2014). Lee et al. $(2010,2011)$ evaluated the effect of different approaches of curd washing (i.e., addition of cold water to curds after total drainage of the whey; $\mathbf{C W}$ ) in the manufacture of Colby cheese and found that, similar to $\mathrm{WD}$, the use of $\mathrm{CW}$ led to decreased amounts of residual lactose and lactic acid in cheese.

Many factors influence the ability of WD or CW to reduce the lactose or lactic acid levels in cheese. These factors include the amounts of water involved, temperature, composition of milk (changes in lactose levels), curd particle size, time involved in the washing or dilution step, and others.

Low-concentration-factor ultrafiltration (LCF-UF) has been successfully used for milk protein standardization in the manufacture of many cheese varieties, including Parmesan (Govindasamy-Lucey et al., 2004), pizza-style (Govindasamy-Lucey et al., 2005), and Swiss (Govindasamy-Lucey et al., 2011). These studies have shown that cheeses of similar quality and composition can be obtained if certain process variables (e.g., coagulation conditions, amount of starters, rennet, and salt) are modified to account for the increased protein content of the milk. However, when increasing the protein level with LCF-UF, the lactose content of milk remains similar, which alters the lactose-to-casein ratio (L:CN), which could in turn influence the acidity of cheese. Although the lactose content of the serum portion of UF milk is similar to that of non-UF milk, the buffering capacity of UF milk is increased due to its higher casein content. Johnson and Lucey (2006a) pointed out that diafiltration, the addition of water to the UF retentate, could be a useful tool to help control the lactose content of UF retentates. The greater the concentration factor of the UF milk before diafiltration, the less water would be needed to reduce the lactose content of a cheesemilk - that is, to achieve a lower L:CN. Traditional practices, such as WD and CW, use a lot of water to dilute the whey, which adds to the expense of concentrating whey for the manufacture of higher-protein whey products. Recently, Moynihan et al. (2016) used lactose standardization (LS) of milk, altering the lactose content of LCF-UF cheesemilk by adding water purified by reverse osmosis, to control acidity in low-moisture part-skim Mozzarella cheese.

This study compares WD with the addition of water to UF retentate, LS, for the manufacture of low- $(\mathbf{L F})$ and reduced-fat (RF) Gouda cheese. Gouda cheese was selected because it traditionally uses WD as a means of reducing lactose content in the cheese (Van den Berg et al., 2004). Although the amount of water added during Gouda manufacture can vary (approx. 15 to $25 \%$ ), we selected 2 levels of WD for this study: higher (30\%; WD30) and lower (15\%; WD15). We used a milled curd, direct-salt protocol to manufacture the Gouda cheeses, because some Gouda cheesemakers in the United States use this approach, producing cheese with a smoother mouthfeel than the stirred curd procedure currently used by many US manufacturers of Gouda, according to our research.

\section{MATERIALS AND METHODS}

\section{Ultrafiltration of Milk}

Raw skim milk was obtained from the University of Wisconsin-Madison Dairy Plant. Two days before cheese manufacture, skim milk was subjected to UF as described by Govindasamy-Lucey et al. (2005), until TS levels were approximately $13.5 \%$ (wt/wt). Processing was performed at $\leq 7^{\circ} \mathrm{C}$, and milk was recirculated through a UF unit (modified APV North America Inc., Tonawanda, NY) fitted with 4 spiral-wound polyethersulphone membranes (model ST3B4338, Synder Filtration, Vacaville, CA) with a molecular weight cutoff of $10 \mathrm{kDa}$ and a total membrane area of $32.8 \mathrm{~m}^{2}$. The retentate and permeate were stored overnight at $4^{\circ} \mathrm{C}$ and analyzed for composition.

\section{Standardization of Milks and Cheese Manufacture}

Four separate trials of milled curd, direct-salted Gouda cheeses were made at the University of WisconsinMadison dairy processing plant. For each trial, 1 vat of cheese was made for each variable, and a total of 6 $272-\mathrm{kg}$ vats of milk were manufactured per trial. The 
variables were 2 fat levels (LF or RF) and 3 methods of lactose reduction: 2 levels of WD (WD15 and WD30) or LS. Milks were standardized using raw skim milk $(9.4 \pm 0.2 \% \mathrm{TS} ; 2.5 \pm 0.1 \% \mathrm{CN} ; 0.4 \pm 0.1 \%$ fat; 4.3 $\pm 0.1 \%$ lactose; values $\pm \mathrm{SD})$ and sweet cream (37.7 $\pm 6.2 \%$ TS; $1.6 \pm 0.2 \% \mathrm{CN} ; 31.4 \pm 6.7 \%$ fat; $3.0 \pm$ $0.3 \%$ lactose) to obtain milks of the desired fat content and a L:CN of approximately 1.8 (normal ratio in milk; Table 1). Additionally, for each fat level, some milk was separately standardized by blending UF retentate $(13.5 \pm 0.1 \% \mathrm{TS} ; 5.6 \pm 0.2 \% \mathrm{CN} ; 0.2 \pm 0.0 \%$ fat; 4.3 $\pm 0.2 \%$ lactose), UF permeate $(5.4 \pm 0.1 \% \mathrm{TS} ; 4.1 \pm$ $0.1 \%$ lactose), sweet cream, and tap water to adjust the L:CN ratio to approximately 1.2 (reduced lactose; Table 1). All standardized milks had similar CN:fat ratios (Table 2), and milks were pasteurized at $73^{\circ} \mathrm{C}$ for $19 \mathrm{~s}$ and cooled to $31^{\circ} \mathrm{C}$. The cheesemaking protocol for the manufacture of LF and RF treatments was slightly modified to obtain similar firmness values of rennet gels at cutting, as well as similar moisture contents. Milks were preacidified with lactic acid $(25 \%$, wt/wt) to reduce the $\mathrm{pH}$ (6.38 for LF milks and 6.45 for RF milks) and inoculated with direct-vat-set mesophilic cultures comprising Lactococcus lactis ssp. cremoris, Leuconostoc spp., Lactococcus lactis ssp. lactis, and Lactococcus lactis ssp. lactis biovar. diacetylactis blend (CHN-19, Chr. Hansen, Milwaukee, WI; 39.7 g/100 kg of milk for LF, and $36.4 \mathrm{~g} / 100 \mathrm{~kg}$ of milk for RF). An adjunct, Lactobacillus helveticus (LH-32; Chr. Hansen), was added at a rate of 3.7 or $3.3 \mathrm{~g} / 100 \mathrm{~kg}$, respectively, for $\mathrm{LF}$ and $\mathrm{RF}$ milks, and ripened for $30 \mathrm{~min}$ with continuous slow stirring. In all vats, $\mathrm{CaCl}_{2}(33 \%$, wt/ wt) was added (35.7 and $32.7 \mathrm{~mL} / 100 \mathrm{~kg}$ of milk for LF and RF, respectively) and equilibrated for an additional 10 min. Double-strength fermentation-produced bovine calf chymosin $(600 \mathrm{IMCU} / \mathrm{mL}$, CHY-MAX Extra, Chr. Hansen) was then added to each vat $(8.8 \mathrm{~mL}$ or $8.1 \mathrm{~mL} / 100 \mathrm{~kg}$ of milk for $\mathrm{LF}$ and $\mathrm{RF}$, respectively). The coagula were cut at similar firmness (approx. 50 min), as determined by an experienced licensed Wisconsin cheesemaker. The coagulum was cut with vertical (1.27-cm spacing between wires) and horizontal (1.91-cm spacing between wires) knives. The $\mathrm{pH}$ of the coagulum at cutting was 6.23 and 6.26 for $\mathrm{LF}$ and RF cheeses, respectively. After $10 \mathrm{~min}$ of gentle agitation, whey was partially removed from cheese vats at levels of 30\% (WD30) and 15\% (WD15) based on the total volume of curd and whey, and replaced to each vat's original volume with tap water (temperature of approx. $34.4^{\circ} \mathrm{C}$ ). The LS treatments did not have any WD step during cheesemaking. Curds and whey were heated and stirred at $36.7^{\circ} \mathrm{C}$ until the $\mathrm{pH}$ of curds decreased to approximately 6.05 (approx. $20 \mathrm{~min}$ ), when whey was drained from the vats. The matted curds were then cut into slabs, stacked 3 high, inverted every $15 \mathrm{~min}$, and milled at approximately $\mathrm{pH} 5.5$. Milled curds were then salted to their appropriate levels (285 or $262 \mathrm{~g} / 100 \mathrm{~kg}$ of milk for LF and RF, respectively) over a 15-min period (3 equal applications every $5 \mathrm{~min}$ ). The cheeses were hooped into approximately 11-kg blocks and pressed for $3 \mathrm{~h}$ at a pressure of $2.81 \mathrm{~kg} / \mathrm{cm}^{2}$ and held at room temperature overnight. Cheeses were vacuum packaged, initially stored at $10^{\circ} \mathrm{C}$ for the first $21 \mathrm{~d}$, and then stored at $5^{\circ} \mathrm{C}$ for the rest of the 180 -d ripening period.

\section{Compositional Analyses}

Raw skim milk, sweet cream, UF retentate, UF permeate, and standardized milks were analyzed for TS (Green and Park, 1980), total protein (Kjeldahl method; AOAC International, 2000), CN (AOAC International, 2000), NPN (AOAC International, 2000), fat (Mojonnier method; AOAC International, 2000),

Table 1. Average composition and weights of skim milk, cream, UF skim milk retentate, and permeate used to prepare the standardized milks in the manufacture of low-fat (LF) and reduced-fat (RF) Gouda-style cheeses; values represent means and SD, with the latter in parentheses $(\mathrm{n}=4)$

\begin{tabular}{|c|c|c|c|c|c|}
\hline Item & Skim milk & Cream & UF skim milk retentate & Permeate & Tap water \\
\hline Fat & $0.39(0.08)$ & $31.38(6.67)$ & $0.20(0.02)$ & $0.01(0.01)$ & - \\
\hline Casein & $2.49(0.03)$ & $1.55(0.19)$ & $5.57(0.15)$ & $0.01(0.01)$ & - \\
\hline Lactose & $4.25(0.13)$ & $3.00(0.34)$ & $4.30(0.15)$ & $4.05(0.06)$ & - \\
\hline \multicolumn{6}{|l|}{ Weight (\%) } \\
\hline RF WD & 97.1 & 2.9 & - & - & - \\
\hline RF LS & - & 3.8 & 43.2 & 21.0 & 32.0 \\
\hline
\end{tabular}

${ }^{1}$ Milk used to manufacture LF or RF Gouda-style cheese made with whey dilution step (WD).

${ }^{2}$ Lactose standardized (LS) milk used to manufacture LF or RF Gouda-style cheese made without whey dilution step. 
lactose (high-performance ion-exchange chromatography, HPIC; Dionex ICS-5000 RFIC-EG Dual System, Thermo Fisher Scientific Inc., Waltham, MA; Møller et al., 2012), and total calcium (inductively coupled argon plasma emission spectroscopy). The proportion of insoluble calcium (INSOL Ca) of milks was measured by analyzing the calcium content of rennet whey to estimate the content of soluble Ca (Lucey et al., 1993; Hassan et al., 2004). The composition of cheeses was measured after $14 \mathrm{~d}$ of ripening, for moisture (Marshall, 1992), fat (AOAC International, 2000), total protein (AOAC International, 2000), salt (via the chloride electrode method; MK II chloride analyzer 926, Nelson and Jameson Inc., Marshfield, WI; Johnson and Olson, 1985a), and total Ca (Park, 2000). The $\mathrm{pH}$ of cheeses was measured at $1,7,30,90$, and $180 \mathrm{~d}$ of ripening by inserting a spear-tip $\mathrm{pH}$ probe into a cheese block previously held at $20^{\circ} \mathrm{C}$ for $45 \mathrm{~min}$. The concentrations of lactose, galactose, and lactic acid in cheese were measured via HPIC (Møller et al., 2012) at 1, 7, 30, 90, and $180 \mathrm{~d}$ of ripening. Cheese extracts used for chromatographic analyses were prepared according to the method described by Zeppa et al. (2001). The proportion of INSOL Ca in cheese was determined through the acid-base titration method (Hassan et al., 2004) at $1,14,30,90$, and $180 \mathrm{~d}$ of ripening. All analyses were performed in duplicate.

\section{Proteolysis}

Proteolysis was assessed by measuring $\mathrm{pH}$ 4.6soluble nitrogen (Kuchroo and Fox, 1982) and 12\% trichloroacetic acid-soluble nitrogen (AOAC International, 2000) at 1, 14, 30, 90, and $180 \mathrm{~d}$ of ripening. Urea-PAGE was performed directly on cheese samples to monitor the breakdown of $\alpha_{S 1^{-}}$and $\beta-C N$ during ripening, as described by Ibáñez et al. (2016). Densitometric analysis of scanned gels was performed using an image-processing software (GelAnalyzer 2010 1.6, Lazarsoftware, Debrecen, Hungary). All treatments were analyzed in duplicate.

\section{Textural and Rheological Measurements}

Texture profile analysis (TPA) was performed using a Texture Analyzer TA-XT2 (Stable Micro Systems, Godalming, Surrey, UK) at 14, 30, 60, 90, and $180 \mathrm{~d}$ of ripening, using a modified procedure of Ibáñez et al. (2016). Modifications included the use of $30 \%$ strain to compress the cheese sample in 2 consecutive cycles at a rate of $0.8 \mathrm{~mm} / \mathrm{s}$. At least 5 cheese cylinders were analyzed per treatment.

Rheological properties of cheeses were studied by dynamic small-amplitude oscillatory rheology (Govindasamy-Lucey et al., 2005) using a controlled-stress rheometer (MCR 302, Anton Paar Inc., Ashland, VA) at $14,30,60,90$, and $180 \mathrm{~d}$ of cheese ripening. Cheese was heated to $85^{\circ} \mathrm{C}$ at a rate of $1^{\circ} \mathrm{C} / \mathrm{min}$, using a frequency of $0.08 \mathrm{~Hz}$ and a strain of $0.5 \%$. Storage modulus $\left(\mathbf{G}^{\prime}\right)$, loss modulus $\left(\mathbf{G}^{\prime \prime}\right)$, and loss tangent ( $\mathbf{L T}$, which is the ratio between the viscous and the elastic properties of the material, $\mathrm{LT}=\mathrm{G}^{\prime \prime} / \mathrm{G}^{\prime}$ ) were measured during cheese heating. The temperature at the crossover point (where $\mathrm{G}^{\prime}=\mathrm{G}^{\prime \prime}$ or $\mathrm{LT}=1$ ) was also calculated, as this

Table 2. Composition of the standardized milks used in the manufacture of low-fat (LF) and reduced-fat (RF) Gouda-style cheeses (n $=4$ )

\begin{tabular}{|c|c|c|c|c|c|c|c|}
\hline \multirow[b]{2}{*}{ Item } & \multicolumn{3}{|c|}{$\mathrm{LF}$} & \multicolumn{3}{|c|}{$\mathrm{RF}$} & \multirow[b]{2}{*}{ SEM } \\
\hline & WD $30^{1}$ & $\mathrm{WD} 15^{2}$ & $\mathrm{LS}^{3}$ & WD30 & WD15 & LS & \\
\hline $\mathrm{CN}(\%)$ & $2.42^{\mathrm{a}}$ & $2.44^{\mathrm{a}}$ & $2.43^{\mathrm{a}}$ & $2.35^{\mathrm{a}}$ & $2.43^{\mathrm{a}}$ & $2.42^{\mathrm{a}}$ & 0.011 \\
\hline Lactose (\%) & $4.08^{\mathrm{b}}$ & $4.20^{\mathrm{ab}}$ & $2.66^{\mathrm{d}}$ & $4.18^{\mathrm{ab}}$ & $4.25^{\mathrm{a}}$ & $2.93^{\mathrm{c}}$ & 0.138 \\
\hline $\mathrm{L}: \mathrm{CN}$ ratio ${ }^{4}$ & $1.69^{\mathrm{a}}$ & $1.72^{\mathrm{a}}$ & $1.10^{\mathrm{c}}$ & $1.78^{\mathrm{a}}$ & $1.75^{\mathrm{a}}$ & $1.21^{\mathrm{b}}$ & 0.059 \\
\hline CN:fat ratio & $5.34^{\mathrm{a}}$ & $5.35^{\mathrm{a}}$ & $5.34^{\mathrm{a}}$ & $1.96^{\mathrm{b}}$ & $1.94^{\mathrm{b}}$ & $2.02^{\mathrm{b}}$ & 0.357 \\
\hline Soluble Ca (mg/100 g) & $32.0^{\mathrm{a}}$ & $32.3^{\mathrm{a}}$ & $24.1^{\mathrm{b}}$ & $31.2^{\mathrm{a}}$ & $30.8^{\mathrm{a}}$ & $23.1^{\mathrm{b}}$ & 1.17 \\
\hline INSOL $\mathrm{Ca}^{5}(\mathrm{mg} / 100 \mathrm{~g})$ & $78.0^{\mathrm{a}}$ & $76.7^{\mathrm{a}}$ & $72.9^{\mathrm{a}}$ & $70.8^{\mathrm{a}}$ & $71.2^{\mathrm{a}}$ & $72.9^{\mathrm{a}}$ & 2.48 \\
\hline INSOL $\mathrm{Ca}(\mathrm{mg} / \mathrm{g}$ of $\mathrm{CN})$ & $32.2^{\mathrm{a}}$ & $31.5^{\mathrm{a}}$ & $30.0^{\mathrm{a}}$ & $30.2^{\mathrm{a}}$ & $29.3^{\mathrm{a}}$ & $30.0^{\mathrm{a}}$ & 0.878 \\
\hline INSOL Ca $(\mathrm{g} / 100 \mathrm{~g}$ of total Ca) & $70.6^{\mathrm{b}}$ & $70.1^{\mathrm{b}}$ & $74.8^{\mathrm{a}}$ & $69.3^{\mathrm{b}}$ & $70.1^{\mathrm{b}}$ & $75.6^{\mathrm{a}}$ & 0.934 \\
\hline
\end{tabular}

${ }^{\mathrm{a}-\mathrm{f}}$ Means within the same row not sharing a common superscript differ $(P<0.05)$, as compared by Tukey multiple comparison test.

${ }^{1}$ Whey dilution (WD) of cheese vat at level of $30 \%$.

${ }^{2} \mathrm{WD}$ of cheese vat at level of $15 \%$.

${ }^{3}$ Lactose standardization (LS) of milk by ultrafiltration and water addition.

${ }^{4} \mathrm{~L}: \mathrm{CN}=$ lactose-to-casein ratio

${ }^{5}$ INSOL $\mathrm{Ca}=$ amount of insoluble colloidal calcium phosphate. 
corresponds to the transition from solid to liquid-like material.

\section{Descriptive Sensory Analysis}

Texture and flavor attributes of the cheeses were monitored by a combination of the sensory Spectrum technique and quantitative sensory analysis (Meilgaard et al., 1999; Moynihan et al., 2016). At least 12 panelists $(>20 \mathrm{~h}$ of training) evaluated samples in duplicate at $30,60,90$, and $180 \mathrm{~d}$ of ripening. Each sample was identified with a random 3 -digit code. Cheese cubes (2 $\times 2 \times 2 \mathrm{~cm}$ ) were evaluated at $12^{\circ} \mathrm{C}$, using a numerical scale ranging from 0 to 15 . Attributes described (Table 3) were texture (hand firmness, cohesiveness, chewiness, and particle size), basic taste and flavors (sweet, salt, acid, bitter, milkfat, brothy, sour, and cardboard), and astringency.

\section{Experimental Design and Statistical Analyses}

Six treatments were carried out based on the 2 milk fat levels and 3 lactose modification techniques, namely: LF cheese (approx. 6\% fat), normal milk lactose, 30\% whey dilution (LF-WD30); LF cheese, normal milk lactose, $15 \%$ whey dilution (LF-WD15); LF cheese, lactose in milk standardized by UF (LF-LS); RF cheese (14 to $15 \%$ fat), normal milk lactose, $30 \%$ whey dilution (RF-WD30); RF cheese, normal milk lactose, $15 \%$ whey dilution (RF-WD15); and RF cheese, lactose in milk standardized by UF (RF-LS). A $6 \times 4$ completely randomized block design that incorporated all 6 treatments and 4 cheesemaking days was used for analysis of the response variables relating to cheese composition. Analysis of variance (ANOVA) was performed at a significance level of $P<0.05$. A split-plot design (Montgomery, 2013) was used to evaluate the effects

Table 3. Definition of the attributes used by trained panelists to evaluate the sensory properties of low-fat (LF) and reduced-fat (RF) Goudastyle cheeses at $12^{\circ} \mathrm{C}$ using a combination of Spectrum and quantitative descriptive analysis ${ }^{1}$

\begin{tabular}{|c|c|c|}
\hline Attribute & Definition and evaluation procedure & $\begin{array}{l}\text { References used, preparation instructions, } \\
\text { and anchor points }(0-15)\end{array}$ \\
\hline Hand firmness & $\begin{array}{l}\text { Force required to compress the cheese between finger } \\
\text { and thumb. } \\
\text { Place the cheese cube between thumb and forefinger. } \\
\text { Compress cheese cube to approximately } 30 \% \text { its } \\
\text { original size; do not fracture. }\end{array}$ & $\begin{array}{l}\text { Green-colored Theraputty (\#5075; Sammons Preston, } \\
\text { Bolingbrook, IL) }=4.5 \\
\text { Green-colored Theraputty (\#5077; Sammons Preston) }=7.0 \\
\text { Flesh-colored Thera-Putty (Graham-Field Inc., Atlanta, GA) } \\
=9.5 \\
\text { Gray eraser (Primacolor Kneaded Rubber, Oak Brook, IL) } \\
=12.0 \\
\text { White eraser (School Select White, Chamblee, GA) }=15.0\end{array}$ \\
\hline Chewiness & $\begin{array}{l}\text { The total amount of energy required to masticate the } \\
\text { sample to a state pending swallowing. } \\
\text { Place cheese cube between molars, chew cheese cube } \\
\text { at an even rate, both sides of mouth may be used. } \\
\text { Measure total energy required. Chewiness is a product } \\
\text { of cohesiveness, hardness, and springiness. The longer } \\
\text { time required to chew, the chewier the sample. }\end{array}$ & $\begin{array}{l}\text { Philadelphia full-fat cream cheese (Kraft Foods, Chicago, IL) } \\
=1.0 \\
\text { Beef frankfurters (Hebrew National Brand, Chicago, IL) }= \\
4.0 \\
\text { Gum drops (Dots Brand, Chicago, IL) }=9.0 \\
\text { Beef jerky (Jack Links Brand, Minong, WI) }=13.5\end{array}$ \\
\hline Particle size & $\begin{array}{l}\text { Size of the particles in the chewed mass. Chew } 12-15 \\
\text { times and evaluate. }\end{array}$ & $\begin{array}{l}\text { Philadelphia full-fat cream cheese (Kraft Foods) }=0.0 \\
\text { Parmesan cheese (BelGioioso Cheese, Green Bay, WI) }=5.0 \\
\text { Juustoleipa cheese (Babcock Dairy Hall, UW-Madison, } \\
\text { Madison, WI) }=10.0 \\
\text { Medium Cheddar (Kraft Foods) }=15.0\end{array}$ \\
\hline Sweet & Basic taste sensation elicited by sweet compounds. & None to pronounced. \\
\hline Salt & Basic taste sensation elicited by salt. & None to pronounced. \\
\hline Acid & Basic taste sensation elicited by acids. & None to pronounced. \\
\hline Bitter & Basic taste sensation elicited by bitter compounds. & None to pronounced. \\
\hline Milkfat & $\begin{array}{l}\text { Aromatics and flavor commonly associated with milk or } \\
\text { fresh cream. }\end{array}$ & None to pronounced. \\
\hline Brothy & $\begin{array}{l}\text { Aromatics associated with boiled meat or vegetable } \\
\text { soup stock. }\end{array}$ & None to pronounced. \\
\hline Sour & $\begin{array}{l}\text { Aromatics and flavors commonly associated with acid } \\
\text { compounds. }\end{array}$ & None to pronounced. \\
\hline
\end{tabular}

${ }^{1}$ Attributes were evaluated using Spectrum and quantitative descriptive analysis (Meilgaard et al., 1999; Moynihan et al., 2016). 
Table 4. Composition ${ }^{1}$ of low-fat (LF) and reduced-fat (RF) Gouda-style cheeses manufactured using 30\% whey dilution (WD30), 15\% whey dilution (WD15), or standardization of milk lactose by UF (LS) treatment

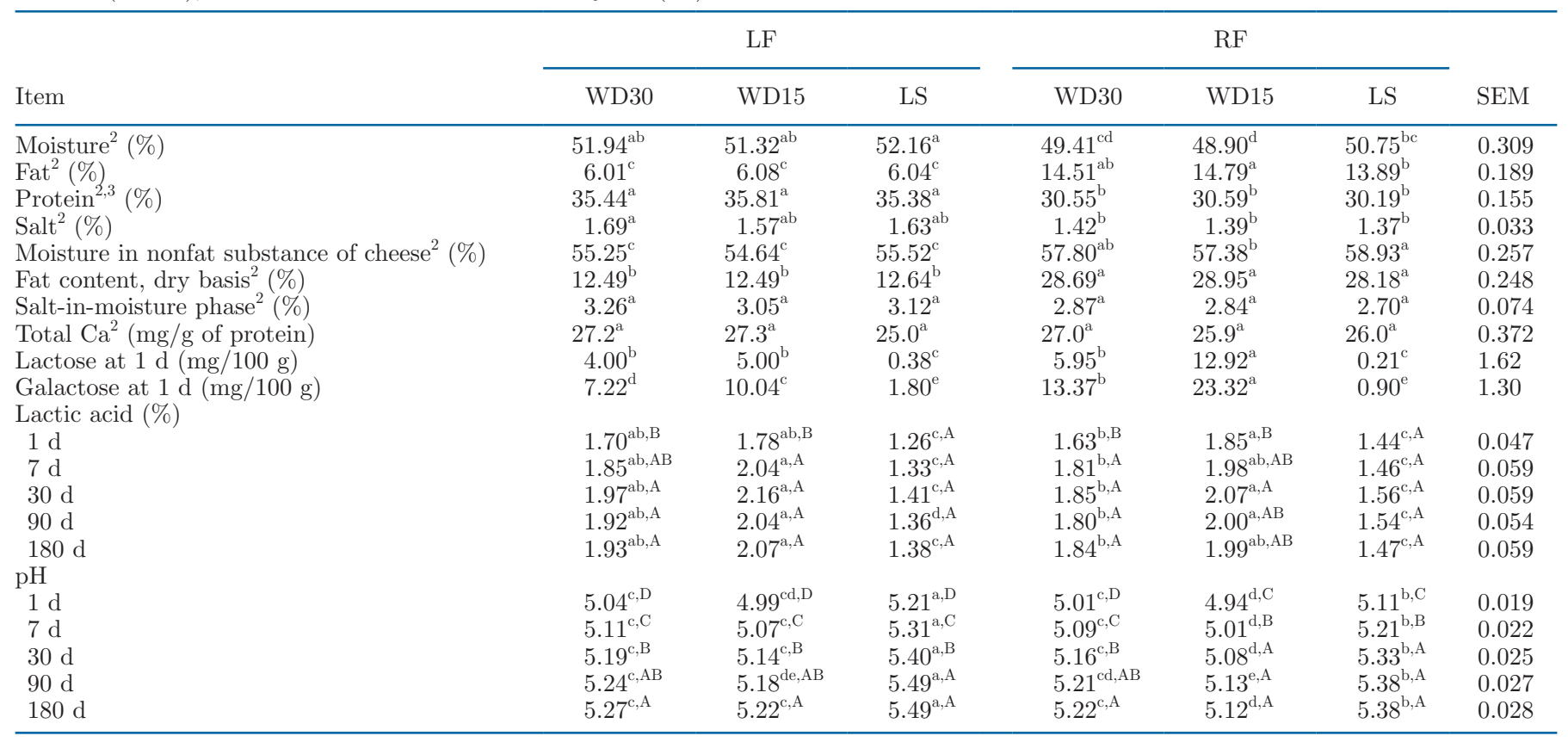

${ }^{\mathrm{a} e}$ Means within the same row not sharing a common lowercase superscript differ $(P<0.05)$, as compared by Tukey multiple comparison test.

${ }^{\mathrm{A}-\mathrm{D}}$ Means within the same column (for a particular parameter) not sharing a common uppercase superscript differ $(P<0.05)$, comparing the effect of ripening time at a single treatment.

${ }^{1}$ Values represent mean and SEM of 4 replicate trials.

${ }^{2}$ Composition measured at $14 \mathrm{~d}$ of ripening.

${ }^{3}$ Total $\% \mathrm{~N} \times 6.38$.

of treatment, ripening time, and their interactions on $\mathrm{pH}$, levels of lactic acid, proteolysis, INSOL Ca, and textural, rheological, and sensory properties. When significant differences $(P<0.05)$ were found, the means of the different treatments were analyzed using Tukey's multiple comparison test. All analyses were performed using Minitab 16 (Minitab Inc., State College, PA).

\section{RESULTS AND DISCUSSION}

\section{Composition of Cheesemilks and Cheeses}

All milks had similar CN contents (approx. 2.4\%; Table 2). Lactose adjustment using UF retentates and subsequent water addition significantly $(P<0.05)$ reduced the lactose content (and TS), leading to a decrease in L:CN levels from 1.7 to 1.8, to 1.1 to 1.2, compared with milks used to make cheese using WD (WD30 or WD15; $P<0.05$ ). In addition, LS treatments exhibited lower levels of total Ca compared with WD treatments.

The fat content of the cheeses were within the range expected for LF and RF cheeses (Table 4). The moisture content of RF cheeses was close to $50 \%$ but was slightly higher in LF cheeses $(P<0.05)$. The mois- ture content between LF cheeses was similar, but the moisture content of RF-LS cheese was slightly higher compared with RF-WD15 $(P<0.05)$. We also found this trend in the moisture in nonfat substance content of RF cheeses. Analysis demonstrated that LF cheeses had similar moisture in nonfat substances among treatments, and they were lower than those of RF cheeses $(P<0.05)$. We found no significant differences in the total $\mathrm{Ca}$ contents of LF or RF cheeses when values were expressed on protein basis $(P>0.05)$. The chemical compositions of all cheeses were similar (Table 4), probably due to the standardization of their cheesemilks to the same CN-to-fat ratios (Table 2). As expected, LF cheeses had lower fat and higher protein contents than did the RF cheeses.

The adjustment of lactose in milk led to LF-LS and RF-LS cheeses with much lower levels of lactose at $1 \mathrm{~d}$ of ripening, compared with cheeses made with WD $(P<$ 0.05; Table 4). The RF-WD15 cheese had significantly higher lactose levels than did other WD treatments $(P$ $<0.05$ ). After $7 \mathrm{~d}$ of ripening, lactose was not detected in any treatment (results not shown). Similarly, much lower levels of galactose at $1 \mathrm{~d}$ were observed in LS cheeses than in WD cheeses $(P<0.05$; Table 4$)$. The WD15 treatment resulted in higher levels of galactose 
compared with WD30 in both LF and RF cheeses $(P<$ $0.05)$. The higher galactose levels in the WD15 cheeses reflected the higher initial lactose concentration (starting substrate) in the cheesemilk as well as reduced whey dilution levels used during the manufacture. After $30 \mathrm{~d}$ of ripening, galactose was not detected in any treatment (results not shown). The mesophilic starter organisms used in this study ferment lactose through a phosphoenolpyruvate phosphotransferase system and do not excrete galactose, but $L b$. helveticus excretes galactose (Lawrence and Thomas, 1979). Thus, initially galactose accumulates in cheese as the result of the metabolism of Lb. helveticus (Callanan and Ross, 2004). However, Lb. helveticus is able to use galactose after all the lactose are used up and conditions are conducive for fermentation (Johnson and Olson, 1985b). This probably contributed to reduction in the levels of residual galactose after $30 \mathrm{~d}$ of ripening.

Initial (d 1) residual lactose levels in cheese were very low in the LS cheeses compared with those made using WD (Table 4), which indicated that the LS treatment more effectively reduced the lactose content in cheese curd than did WD. Cheesemilk with higher initial lactose levels result in higher residual lactose levels in the cheese (Rehman et al., 2004). Dilution of cheese whey using water should encourage more lactose diffusion from the curd particles; however, most curd syneresis occurs within the first 15 min after cutting of the coagulum (Fagan et al., 2017), so it likely occurs before the WD process. In addition, the final moisture contents in these cheeses were about $50 \%$; a high proportion of the water phase (containing lactose) is retained in highmoisture cheeses similar to our experimental RF and LF cheeses. Residual lactose was quickly depleted in all cheeses after manufacture, in agreement with previous studies (Lolkema, 1991; McSweeney and Fox, 2004; Van den Berg et al., 2004). The use of WD and CW to reduce lactose in cheese has been extensively studied for control of the acidity of cheese (Lawrence et al., 1987; Rehman et al., 2004; Lee et al., 2005, 2011; Upreti and Metzger, 2006; Hou et al., 2014).

A significant effect on treatment and cheese age was observed for the levels of lactic acid (Table 5). Cheeses made with LS milks had lower levels of lactic acid at all ripening periods, compared with cheeses made with WD treatments $(P<0.05$; Table 4$)$. For the WD cheeses, levels of lactic acid exhibited a slight increase after $7 \mathrm{~d}$ of ripening and then remained relatively constant for the rest of ripening (Table 4). The $\mathrm{pH}$ values of the cheeses exhibited a significant effect of treatment, cheese age, and interaction of treatment $\times$ cheese age $(P<0.05$; Table 5$)$. At $1 \mathrm{~d}$ of ripening, the $\mathrm{pH}$ values from LS cheeses were significantly higher than those of WD cheeses (Table 4). In the RF cheeses, the $\mathrm{pH}$ values obtained from WD15 treatments tended to be lower than those of WD30 treatments. An increase in $\mathrm{pH}$ values was found for all treatments during ripening $(P<0.05$; Table 4$)$. The lower lactic acids levels in the LS cheeses were in agreement with their higher $\mathrm{pH}$ values throughout ripening (Table 4 ). We observed only slight differences in the lactic acid contents of LF cheeses made with different levels of WD (Table 4). Lawrence et al. (1987) found that the $\mathrm{pH}$ values of 5 -mo Gouda cheeses made from mid- and late-lactation milks were approximately 5.4 and 5.9 , respectively, and they partly attributed the higher $\mathrm{pH}$ values of the cheeses made from late-lactation milk to the lower initial lactose contents of these cheeses. Because milk composition, including lactose levels, changes during the lactation cycle, Lolkema (1991) suggested that the levels of WD applied during Gouda cheese manufacture should be varied based on the composition of milk to achieve the desired cheese $\mathrm{pH}$ value.

Treatment, cheese age, and their interaction had a significant effect on the levels of INSOL Ca in the cheeses during ripening (Table 5). At d 1 of ripening, RF-WD30 and RF-WD15 cheeses exhibited the highest levels of INSOL Ca (>90\%), followed by LF-WD30 and LF-WD15 treatments (approx. 85\%; Figure 1). Cheeses made with LS had lower levels of INSOL Ca than cheeses made with WD $(P<0.05)$, and this trend was also observed throughout ripening. All cheeses exhibited a significant reduction in the amount of INSOL Ca during ripening $(P<0.05)$, and all cheeses made with WD treatments had similar proportions of INSOL $\mathrm{Ca}$ after $90 \mathrm{~d}$ of ripening (Figure 1). The higher $\mathrm{pH}$ values of the LS cheeses during ripening were also associated with lower levels of INSOL Ca (Figure 1). Solubilization of INSOL Ca in cheese releases phosphate ions that buffer (increase) pH (Hassan et al., 2004). All cheeses showed an initial decrease in INSOL Ca, and thereafter levels hardly changed during ripening (Figure 1); similar trends have been reported in other cheese varieties (Hassan et al., 2004; Lee et al., 2010). The total Ca contents of all the cheeses were not significantly different, probably due to their similar making procedures (e.g., acidification profile). Dilution of UF milk with water slightly reduced the total and soluble Ca content of the LS milks. Although we found no significant difference between the INSOL Ca contents in the LS and WD milks, the proportion of INSOL $\mathrm{Ca}$, expressed as a percentage of total $\mathrm{Ca}$, was higher in the LS milks (Table 2). Greater INSOL Ca losses in the LS cheese (Table 3) presumably reflected some losses of soluble $\mathrm{Ca}$ in the UF permeate and dilution of milk by addition of water, which was used for the LS 


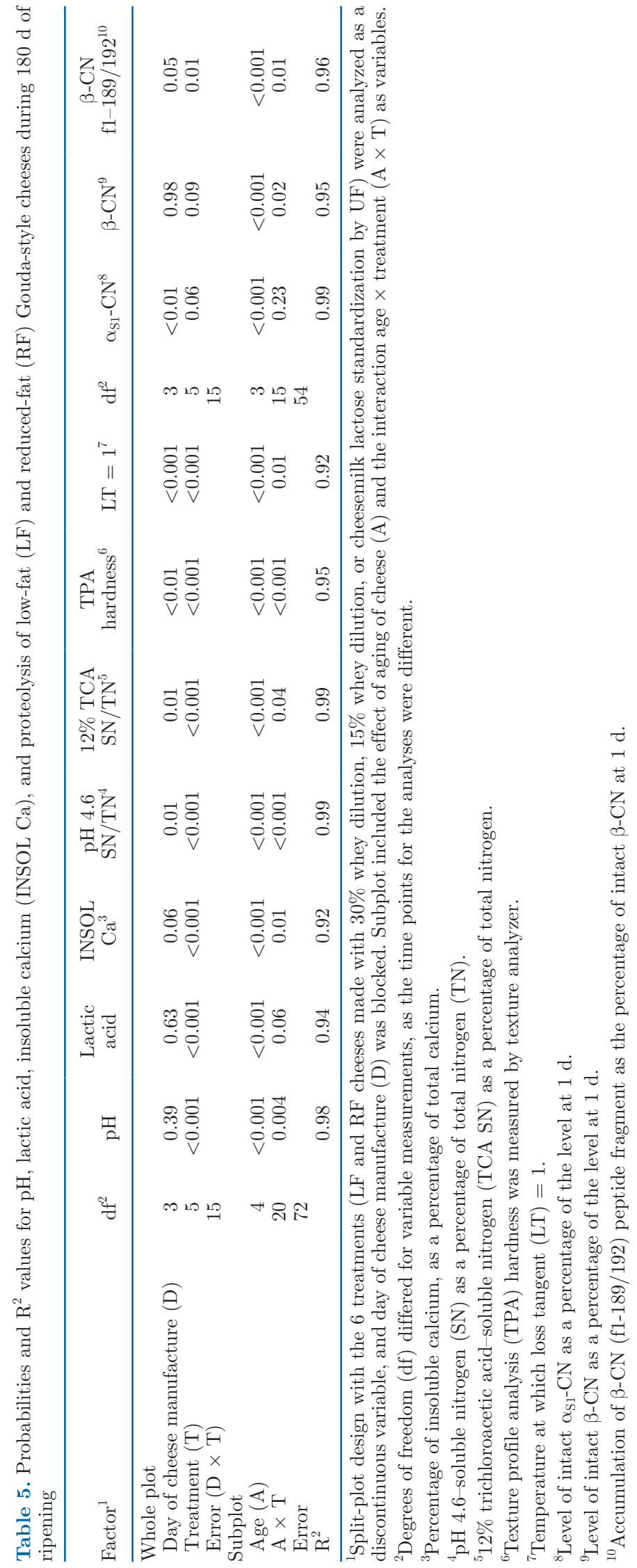




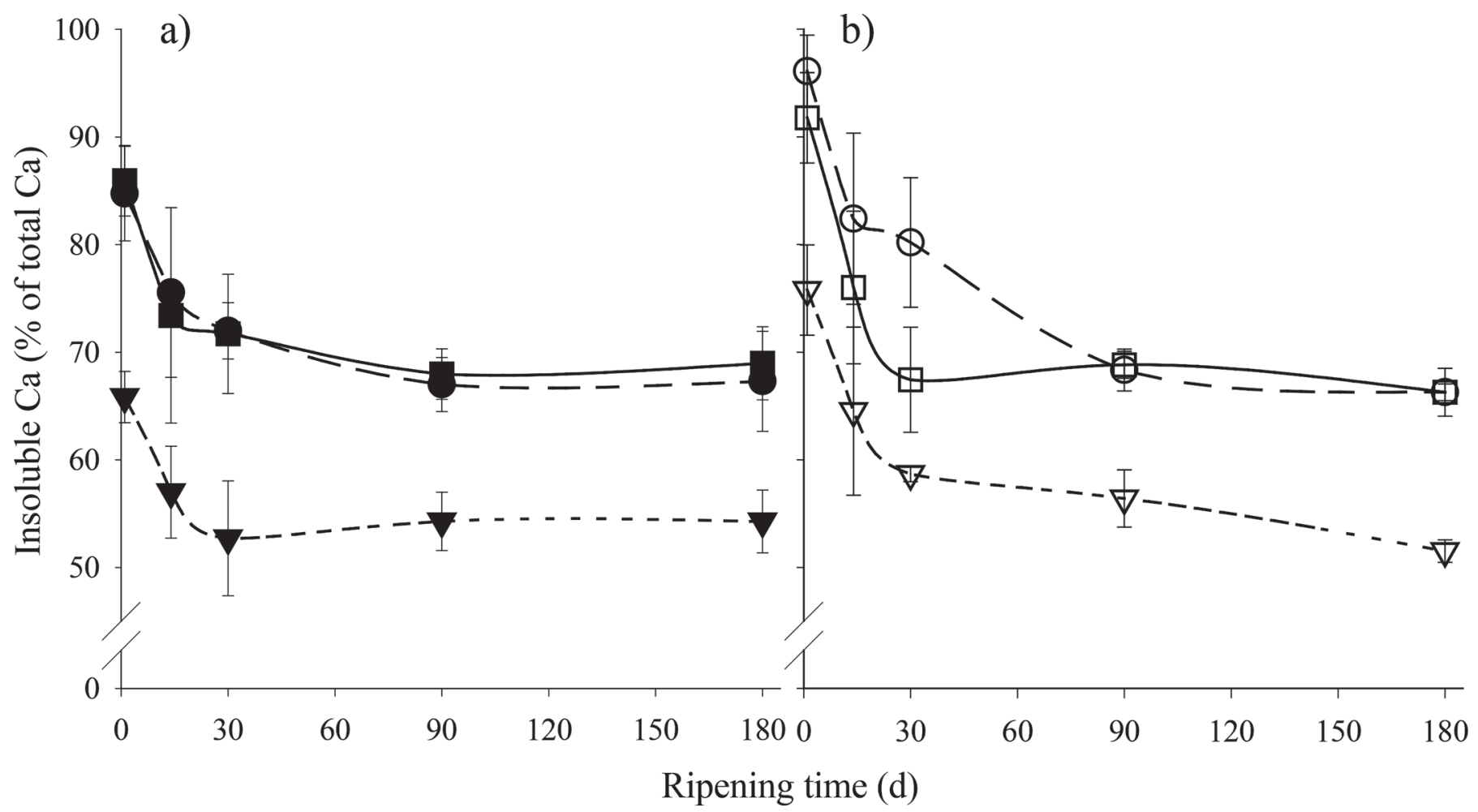

Figure 1. Levels of insoluble calcium, expressed as a percentage of total Ca, of low-fat (filled symbols; a) and reduced-fat (open symbols; b) Gouda-style cheeses made with $30 \%$ whey dilution $(\square)$, $15 \%$ whey dilution $(\bullet)$, or lactose standardization of cheesemilk via low-concentration-factor UF $(\mathbf{\nabla} \nabla)$ during $180 \mathrm{~d}$ of ripening. Values represent mean and SD of 4 replicate trials.

treatments. It was likely that the losses of soluble $\mathrm{Ca}$ in the LS milk samples caused a shift of some INSOL Ca phosphate into the serum phase of the cheese, to attain or re-establish equilibrium, and thus contributed to their lower initial INSOL calcium levels (Figure 1). Moynihan et al. (2016) also found that LS cheesemilk used to manufacture low-moisture part-skim Mozzarella cheeses had reduced levels of INSOL Ca due to the water-addition step.

Cheese $\mathrm{pH}$ values during ripening depend on 2 major factors: lactic acid levels and buffering due to the solubilization of INSOL Ca phosphate (Hassan et al., 2004). The significant increase in the $\mathrm{pH}$ of the LS cheeses during ripening, compared with the WD cheeses (Table 4), was therefore likely due to its lower lactic acid concentration (Table 4) and to the large amount of solubilization of INSOL Ca phosphate (Figure 1), which increases $\mathrm{pH}$ due to buffering by the released phosphate ions.

\section{Proteolysis}

Primary proteolysis of cheeses during ripening, expressed as the level of $\mathrm{pH} 4.6$-soluble $\mathrm{N}$ as a percentage of total N, was affected by treatment, cheese age, and their interaction (Table 5). Levels of proteolysis increased for all treatments during ripening, and similar levels of proteolysis were found during the first $14 \mathrm{~d}$ (Figure $2 \mathrm{a}-\mathrm{b}$ ). After $30 \mathrm{~d}, \mathrm{RF}$ cheeses exhibited slightly higher levels of proteolysis than LF treatments. Similar trends were also observed when secondary proteolysis was assessed by $12 \% \mathrm{TCA}$-soluble $\mathrm{N}$ as a percentage of total N (Figure 2c-d; Table 5). Both LF and RF cheeses made from LS treatments exhibited only slightly lower levels of $12 \%$ trichloroacetic acid-soluble nitrogen compared with WD treatments, indicating only slight differences in proteolysis between the cheeses.

Urea-PAGE electrophoretograms of cheese samples clearly showed an increase in the specific breakdown of $\mathrm{CN}$ during ripening (Figure 3). Hydrolysis of $\alpha_{\mathrm{S} 1}-\mathrm{CN}$ (Figure 4a-b) significantly increased during ripening $(P<0.05)$; however, we found no significant differences among treatments $(P>0.05$; Table 5$)$. Residual chymosin activity in cheese increases with reduction in pH (Mulvihill and Fox, 1980). O'Mahony et al. (2005) reported that greater solubilization of INSOL Ca in cheese might increase the susceptibility of caseins to hydrolysis. The higher $\mathrm{pH}$ of the LS cheeses could have reduced chymosin activity, but that effect may have been offset by the reduced levels of INSOL Ca (i.e., 
increased solubilization of colloidal calcium phosphate) The interaction of treatment $\times$ age significantly afin LS cheeses, which usually favors increased suscepti- fected the breakdown of intact $\beta$-CN (Table 5). Van bility of $\alpha_{S_{1}}$ CN to hydrolysis by chymosin.

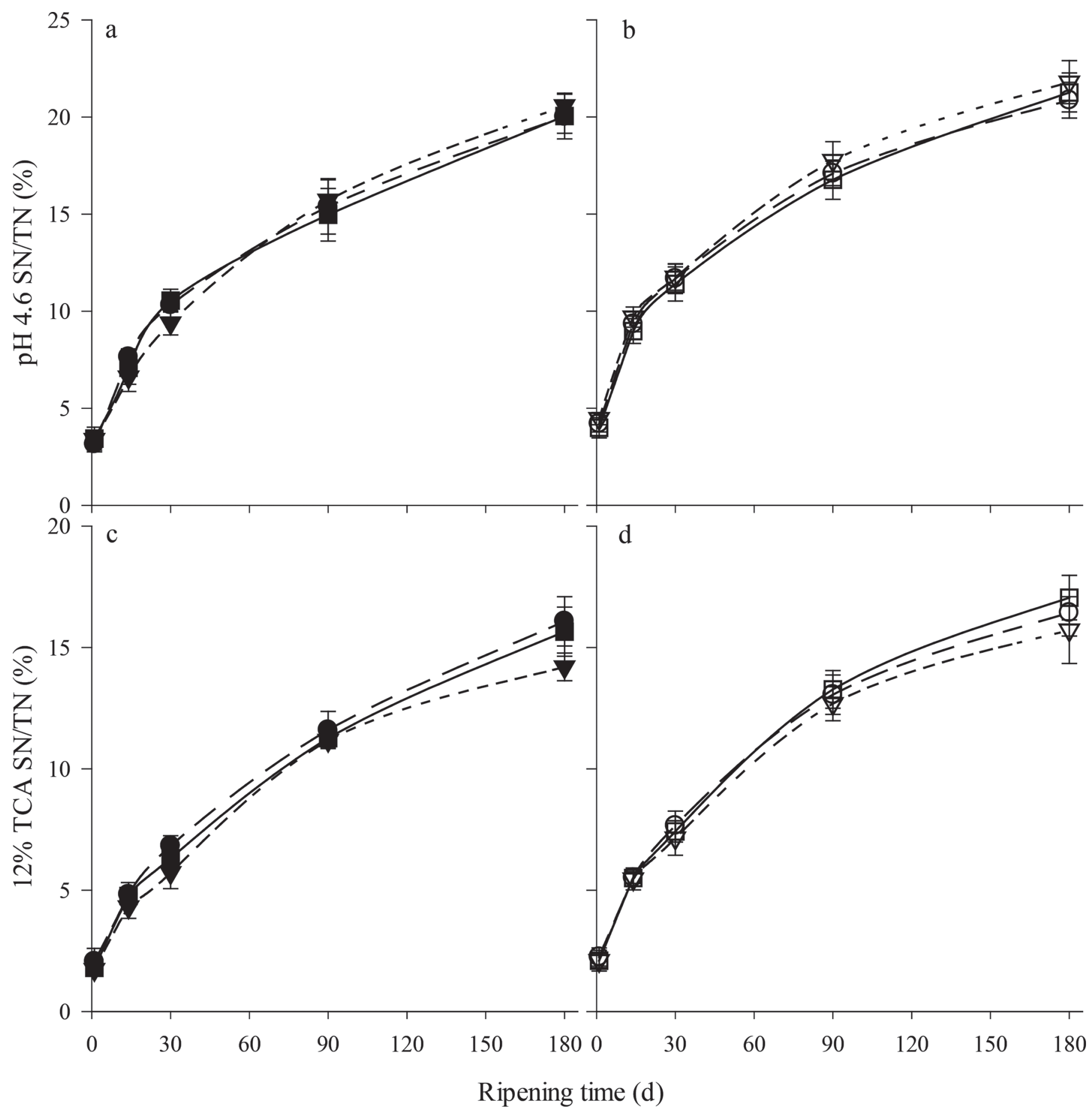

Figure 2. Levels of proteolysis expressed as $\mathrm{pH} 4.6$-soluble N (\% pH $4.6 \mathrm{SN} / \mathrm{TN}$; a and b) and $12 \%$ trichloroacetic acid-soluble N (\% 12 TCA $\mathrm{SN} / \mathrm{TN}$; $\mathrm{c}$ and $\mathrm{d}$ ) as a percentage of total $\mathrm{N}$ found in low-fat (filled symbols) and reduced-fat (open symbols) Gouda-style cheeses made with $30 \%$ whey dilution $(\square \square), 15 \%$ whey dilution $(\bullet)$, or lactose standardization $(\nabla \nabla)$ during $180 \mathrm{~d}$ of ripening. TN $=$ total N. Values represent mean and SD of 4 replicate trials. 
remained intact after the first $60 \mathrm{~d}$ of ripening in Gouda cheese; similar levels were observed in our direct-salted Gouda cheeses (Figure 4a-b). Cheeses made with LS exhibited the lowest levels of intact $\beta-\mathrm{CN}$ after $180 \mathrm{~d}$ of ripening, compared with treatments made with WD $(P<0.05$; Figure $4 \mathrm{c}-\mathrm{d})$ and the highest percentage of
$\beta-\mathrm{CN}$ fragment $\mathrm{f}(189-192)$. Higher hydrolysis of $\beta-\mathrm{CN}$ in cheeses made with LS (Figure 4c-d) may be due to its higher loss of INSOL Ca. The higher pH of LS cheeses (Table 4) could also favor greater plasmin activity. However, we found significant increases in levels of $\beta-\mathrm{CN}$ f(189-192) during the first $30 \mathrm{~d}$ of ripening for
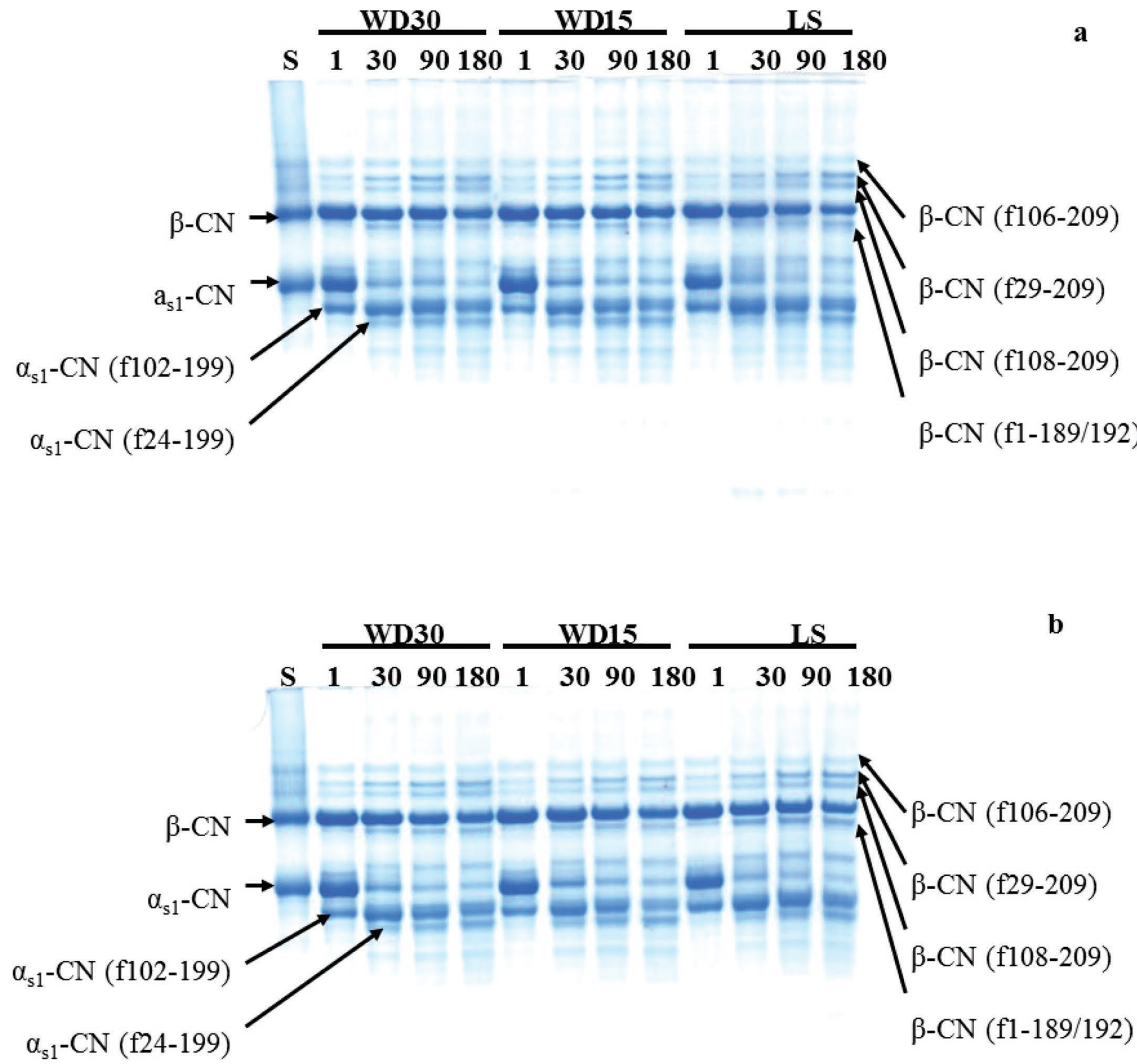

Figure 3. Urea-polyacrylamide gel electrophoresis of low-fat (a) and reduced-fat (b) Gouda-style cheeses at 1, 30, 90, and 180 d of ripening, manufactured with $30 \%$ whey dilution (WD30), $15 \%$ whey dilution (WD15), or lactose standardization (LS). Sodium caseinate (S) was used as molecular weight standard for each gel. 


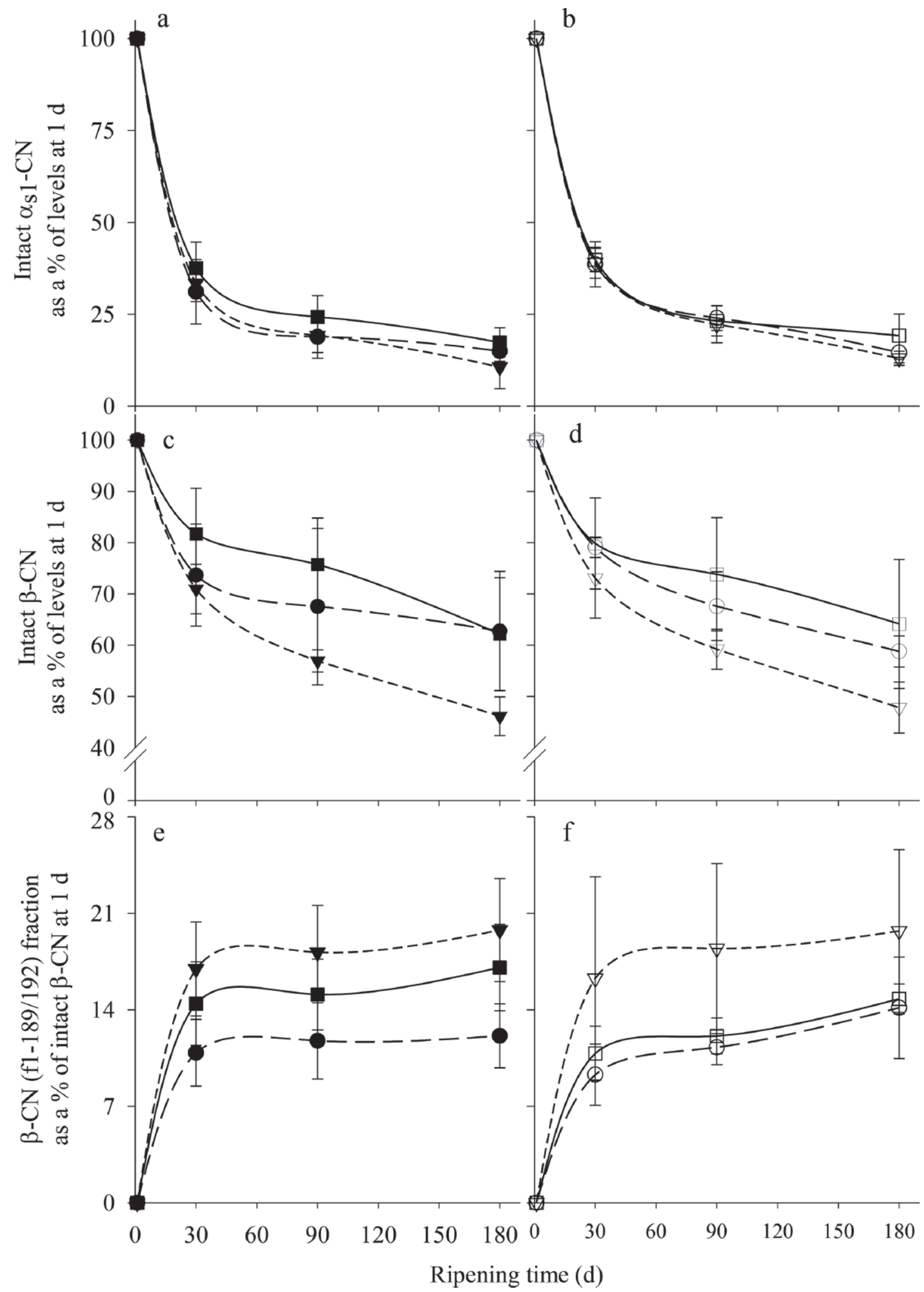

Figure 4. Changes in levels of intact $\alpha_{\mathrm{SI}^{-}} \mathrm{CN}$ as a percentage of the level at $1 \mathrm{~d}(\mathrm{a}, \mathrm{b})$, of intact $\beta$-CN as a percentage of the level at $1 \mathrm{~d}$ (c, $\mathrm{d}$ ), and of intact and accumulation of $\beta$-CN f(189-192) fraction as a percentage of the intact $\beta$-CN level at $1 \mathrm{~d}$ (e, f) for low-fat (filled symbols) and reduced-fat (open symbols) Gouda-style cheeses made with $30 \%$ whey dilution $(\square \square), 15 \%$ whey dilution $(\bullet$ ), or lactose standardization $(\nabla \nabla)$ during $180 \mathrm{~d}$ of ripening. Values represent mean and SD of 4 replicate trials. 


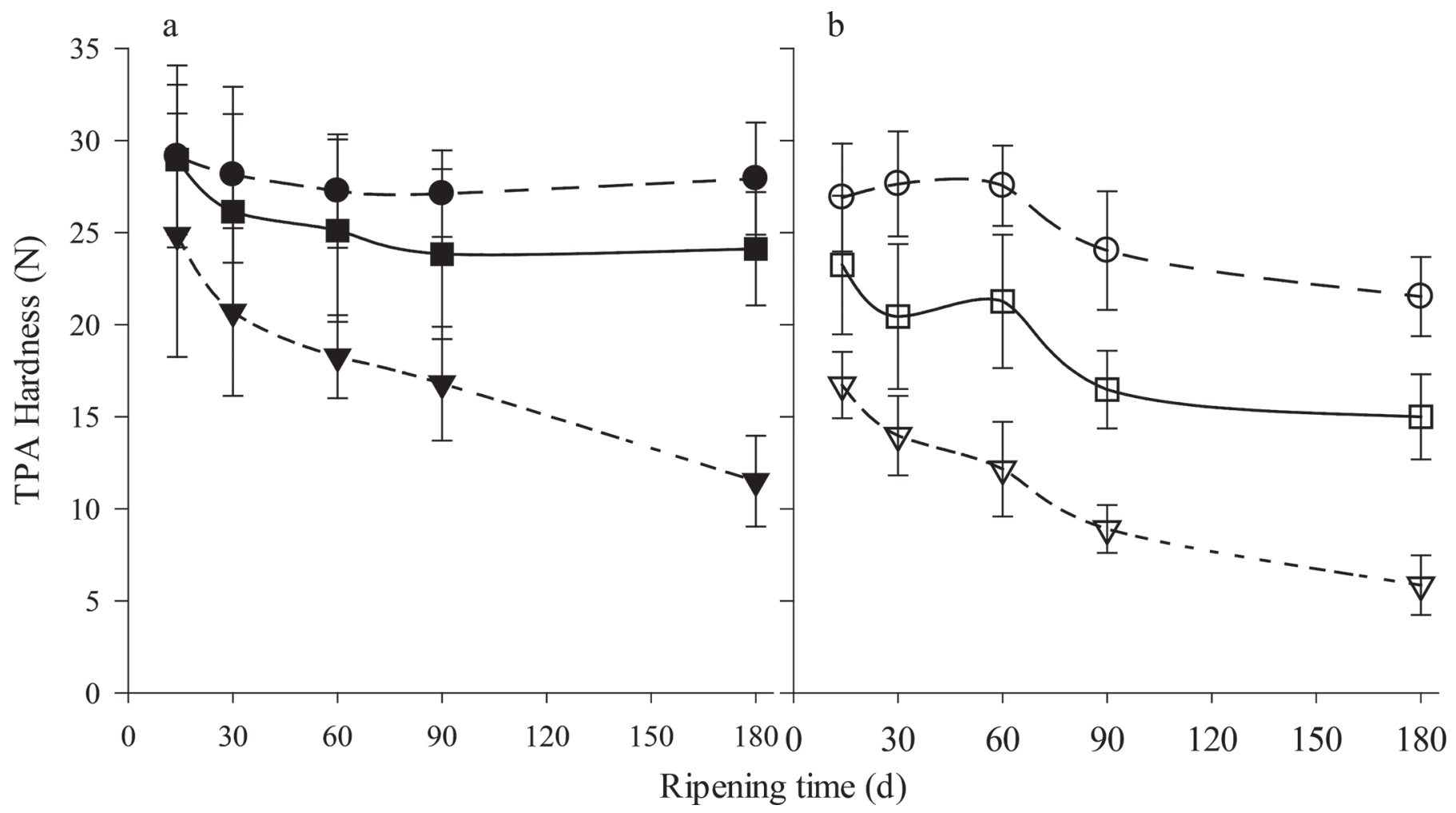

Figure 5. Texture profile analysis (TPA) hardness of low-fat (filled symbols; a) and reduced-fat (open symbols; b) Gouda-style cheeses made with $30 \%$ whey dilution $(\square \square), 15 \%$ whey dilution $(\bullet)$, or lactose standardization $(\nabla \nabla)$ during 180 d of ripening. Values represent mean and $\mathrm{SD}$ of 4 replicate trials.

all treatments (Figure 4e-f; Table 5, $P<0.05$ ). We saw an increase in the formation of $\beta$-CN $\mathrm{f}(189-192)$ in LS cheeses (Figure $4 \mathrm{e}-\mathrm{f}$ ); higher levels of this peptide are usually associated with greater chymosin activity (Feeney et al., 2002). The hydrophobic $\beta-\mathrm{CN}$ f(189-192) and $\beta-\mathrm{CN}$ f(193-209) peptides are products formed from the $\mathrm{C}$-terminal region of $\beta-\mathrm{CN}$ as a result of chymosin action on the $\mathrm{Leu}_{192}-\mathrm{Tyr}_{193}$ bond (Visser and Slanger, 1977). $\beta$-Casein $\mathrm{f}(193-209)$ peptide and some of its degradation products have been identified as significant contributors of bitterness in cheese (Visser et al., 1983). Although $\beta-\mathrm{CN} \mathrm{f}(189-192)$ is not bitter, the presence of this peptide suggests other bitter peptides, such as $\beta-\mathrm{CN} \mathrm{f}(193-209)$ and some of its degradation products, could also be present in the cheese.

\section{Texture and Rheological Properties}

In general, LF cheeses had higher TPA hardness compared with RF samples (Figure 5), possibly due to a higher protein content that leads to a more crosslinked structure (Fenelon and Guinee, 2000; Johnson et al., 2009). A significant decrease in cheese hardness was observed during ripening (Figure 5; Table 5). The occurrence of softening of cheese during ripening is usually attributed to proteolysis, mainly due to degradation of $\alpha_{\mathrm{S}_{1}}$-CN (Creamer and Olson, 1982), as well as to solubilization of INSOL Ca (Lucey et al., 2003; O'Mahony et al., 2005). Throughout ripening, cheeses made with LS exhibited lower hardness values than did WD treatments (Figure 5). Analysis revealed only minor differences in proteolysis between LS and WD treatments until more than $100 \mathrm{~d}$ of ripening (Figure 2), but INSOL Ca levels were significant lower in LS treatments at all ripening points (Figure 1). This suggests that differences in Ca crosslinking may have been larger contributors to the lower hardness of the LS cheeses. Increasing levels of WD in RF cheeses was associated with a softer texture due to decreased levels of INSOL $\mathrm{Ca}$ (Figure 1b). The use of LS resulted in softer cheese compared with WD, probably due to its lower levels of INSOL Ca (Figure 1), even though LS cheeses had the highest $\mathrm{pH}$ (Table 4), which can increase hardness (Watkinson et al., 2001).

During heating, all cheeses showed a decrease in the $\mathrm{G}^{\prime}$ values (results not shown), in agreement with previous studies (Lucey et al., 2003). Treatment, age, and their interactions had significant effects (Table 5) 
on the temperature at which $\mathrm{LT}=1$, or the crossover point (Figure 6). All treatments showed a decrease of the crossover point during ripening (Figure 6), which indicated that when heated, cheeses began to flow (melt) at a lower temperature. Melting is determined by degree of charge repulsion between casein molecules, which is governed by $\mathrm{pH}$, as well as loss of INSOL Ca, but is ultimately governed by the level of proteolysis in aged cheese (Lucey et al., 2003). During the first $60 \mathrm{~d}$ of ripening, only RF-LS cheese exhibited a lower crossover point compared with other treatments (Figure 6). At $180 \mathrm{~d}$ of ripening, the WD15 treatments exhibited the highest crossover temperatures, followed by the 2 WD30 treatments $(P<0.05)$. The LS cheeses had the lowest crossover temperatures after $180 \mathrm{~d}$ of ripening $(P$ $<0.05)$. During cheese ripening, reduction of the melting temperature has been attributed to the combined effects of proteolysis and solubilization of INSOL Ca (Lucey et al., 2003; Govindasamy-Lucey et al., 2005). Cheeses with high $\mathrm{pH}$ values and low INSOL Ca (such as the LS cheeses) readily melt, regardless of the level of proteolysis, and cheeses with high INSOL Ca and high $\mathrm{pH}$ values, or low INSOL $\mathrm{Ca}$ and $\mathrm{pH}$ values $>5.0$, exhibit melting once proteolysis proceeds (Johnson and
Lucey, 2006b). Therefore, several variables, along with their interactions, need to be considered, to understand cheese melting behavior.

\section{Sensory Analysis}

Sensory texture and flavor attributes of the cheeses during ripening are shown in Table 6, and the statistical analyses for the key attributes are shown in Table 7. Attributes of particle size, sweetness, milkfat, brothiness, and cardboard were not significantly different among treatments $(P>0.05$; results not shown). The $\mathrm{RF}$ cheeses generally exhibited lower hand firmness compared with LF, and most cheeses exhibited a decrease in hand firmness during ripening (Table $6, P<$ $0.05)$. Cheeses made with LS were significantly softer than other treatments throughout most of the ripening period. The hand firmness results were in agreement with the results obtained using the instrumental TPA hardness method (Figure 5). Textural differences were mainly attributed to composition, different levels of INSOL Ca caused by WD or LS treatments (Figure 1), and an increase of primary proteolysis during ripening (Figure 2).

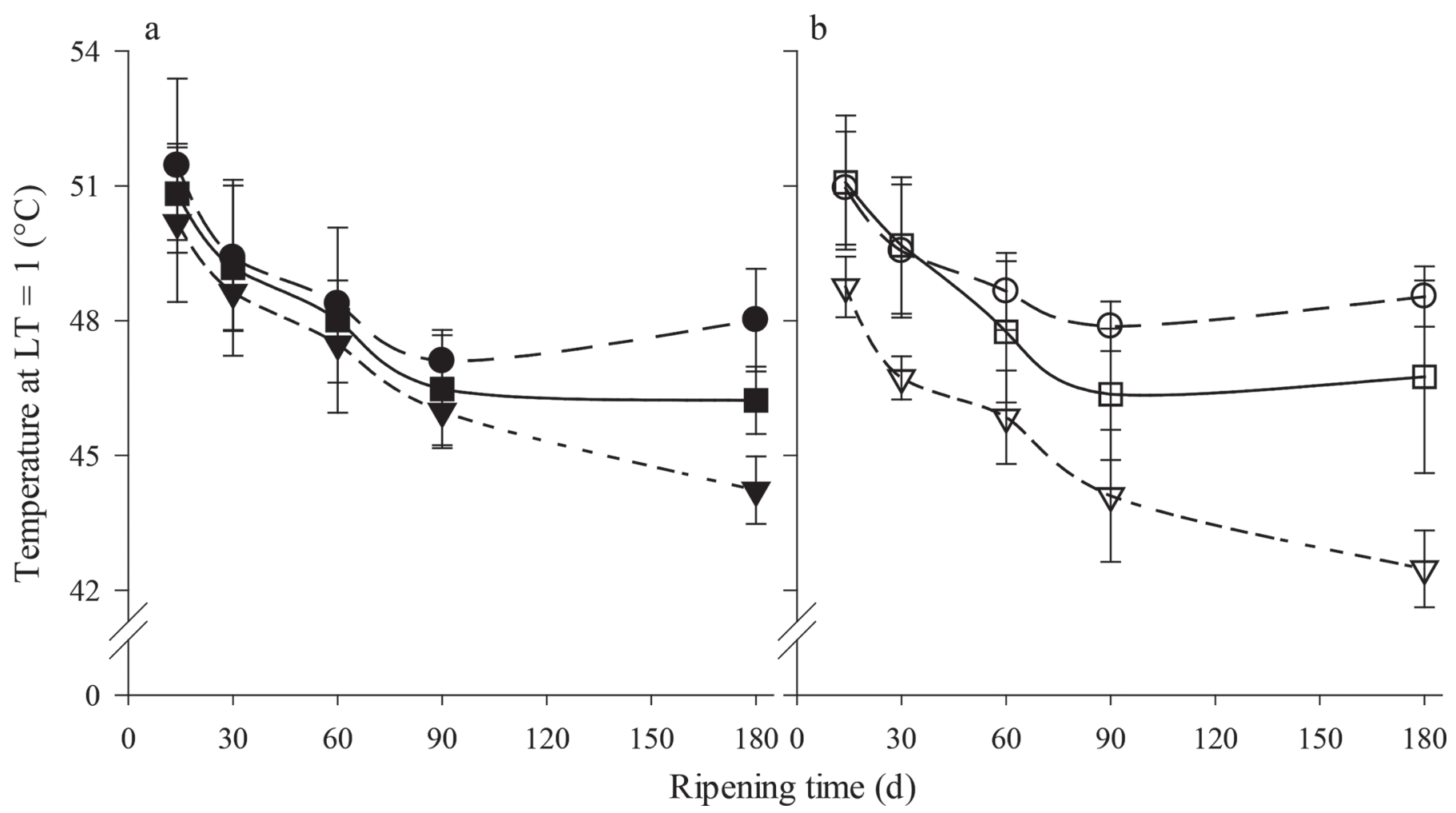

Figure 6. Temperature of the crossover point of the storage and loss moduli [or when loss tangent (LT) $=1$ ] obtained from low-fat (filled symbols; a) and reduced-fat (open symbols; b) Gouda-style cheeses made with $30 \%$ whey dilution $(\square)$ ), $15 \%$ whey dilution $(\bullet \circ)$, or lactose standardization $(\nabla \nabla)$ during $180 \mathrm{~d}$ of ripening. Values represent mean and SD of 4 replicate trials. Parameters measured by dynamic small strain oscillatory testing during the heating of cheese. 
Cohesiveness significantly increased during ripening for cheese samples and was found to be higher in RF than in LF cheeses (Table 6; $P<0.05$ ). The LF cheese made with LS had lower cohesiveness scores than the other treatments at all time points $(P<0.05)$, but little differences occurred for RF cheeses. An increase of the cohesiveness of the mass (degree to which a masticated sample holds together) during ripening could be associated with an increase of primary proteolysis in all treatments, with cohesiveness increasing with more breakdown of texture. Lower cohesiveness, found in all LF chesses, could also be attributed to the slightly lower proteolysis than RF cheeses (Figure 2).

Chewiness was significantly lower in RF compared with LF cheeses, and most cheeses showed a slight decrease ( $<1$ unit) in chewiness during ripening $(P$ $<0.05$ ). It seemed that the cohesiveness and chewiness of cheese samples were also influenced by levels of INSOL $\mathrm{Ca}$ and $\mathrm{pH}$, with lower INSOL Ca contents and higher $\mathrm{pH}$ values associated with lower scores of these attributes, as occurred with cheeses made with LS treatments.

The LS cheeses tended to have slightly lower salt after $90 \mathrm{~d}$ of ripening $(P<0.05)$ and acid scores $(P<$ $0.05)$ than the other treatments. The lower acid scores for LS cheese were in agreement with their lower lactic acid levels (Table 4). Acidity scores did not significantly change during ripening (Table 6), which was also consistent with the trends for lactic acid, which exhibited only a slight increase during the first $7 \mathrm{~d}$ of ripening and thereafter remained constant (Table 4).

Bitterness values were very low during the initial ripening period but significantly increased by $180 \mathrm{~d}$ of ripening for all treatments $(P<0.05)$; in agreement with the increase in key peptide $\beta-\mathrm{CN} f(189-192)$ that has been associated with bitterness during cheese ripening

Table 6. Sensory analysis results of low-fat (LF) and reduced-fat (RF) Gouda-style cheeses manufactured using 30\% whey dilution (WD30), $15 \%$ whey dilution (WD15), or standardization of milk lactose by UF (LS) treatments during $180 \mathrm{~d}$ of ripening ${ }^{1}$

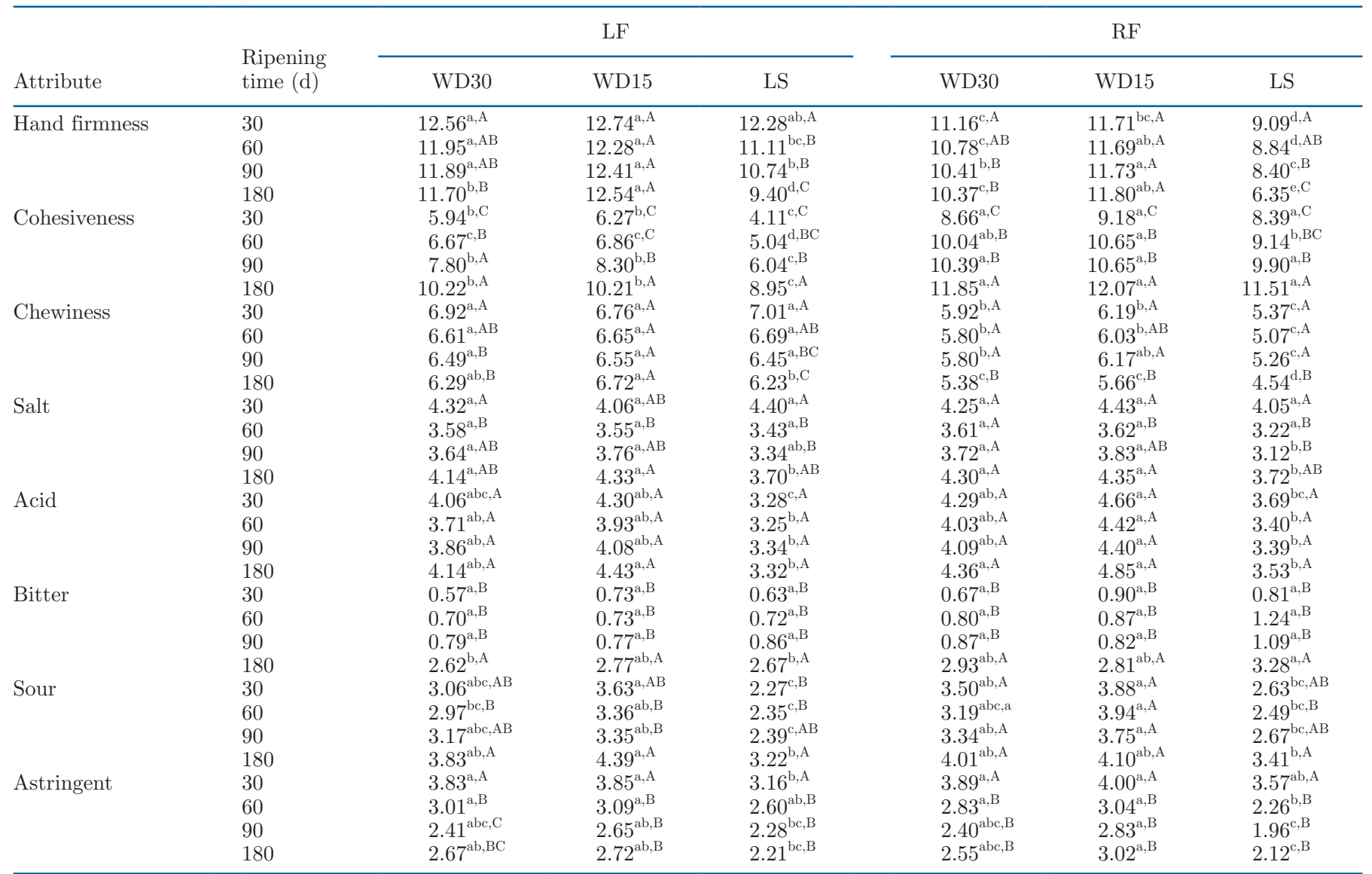

${ }^{\mathrm{a}-\mathrm{d}}$ Means within the same row not sharing a common lowercase superscript differ $(P<0.05)$, comparing the effect of treatment at a single storage time.

${ }^{\mathrm{A}-\mathrm{C}}$ Means within the same column for a particular attribute not sharing a common uppercase superscript differ $(P<0.05)$, comparing the effect of ripening time at a single treatment.

${ }^{1}$ Values represent mean of 4 replicate trials. 


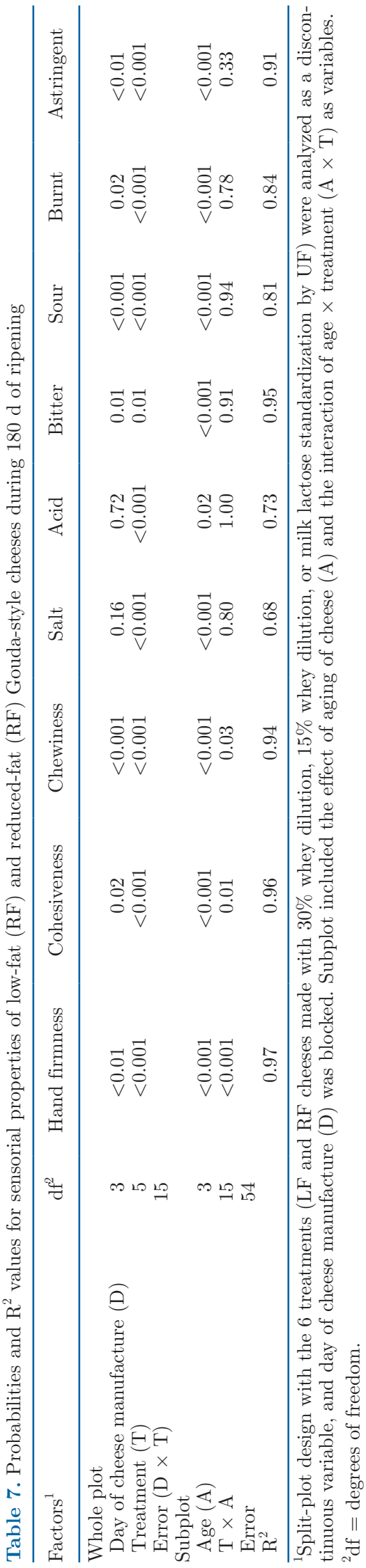

(Figure 4e-f; Singh et al., 2005). A score of 3 was still in the "very slight" category, and it was only detected at that level by expertly trained panelists.

\section{CONCLUSIONS}

Addition of water to UF milk controlled the initial lactose levels in cheesemilk, which helped to prevent excessive acidity in cheeses. Cheeses made from LS had reduced lactose content, along with much lower levels of lactic acid compared with the cheeses manufactured using the WD technique. However, this led to increased $\mathrm{pH}$ values in the LS cheeses. In contrast, increasing the WD level from 15 to $30 \%$ led to only slight decreases in lactose and lactic acid levels, suggesting that this technique should be altered based on milk composition and target cheese $\mathrm{pH}$. The use of LS did result in cheeses with lower INSOL Ca contents, which affected the textural and functional properties of cheeses. Water addition and UF probably resulted in greater losses of soluble $\mathrm{Ca}$ in milk and promoted more solubilization of some INSOL Ca phosphate to re-establish an equilibrium between soluble and insoluble forms. Cheeses made with LS were softer (measured by TPA hardness values) and had lower melt temperatures $(\mathrm{LT}=1)$. Although WD is a critical step during the manufacture of Gouda, it does require the addition of tap water, and this means that additional water will need to be removed during whey processing. Water usage during the cheesemaking process using techniques such as WD or CW could be substantially reduced or eliminated by use of the LS technique. The LS technique can be incorporated into the widespread use of LCF-UF for cheesemilk fortification. Water usage could be substantially reduced, compared with the usage levels in this current study, if UF milk was concentrated to a higher level and then diluted back to the desired lactose level. Better standardization of milk components (lactose, ratio of casein to lactose) would improve the consistency of the Gouda cheesemaking protocol and ultimately help to better standardize cheese composition and functionality.

\section{ACKNOWLEDGMENTS}

The authors thank the personnel of the Wisconsin Center for Dairy Research and University of Wisconsin Dairy Plant (Madison, WI) for their assistance and support in cheese manufacture, analytical work, and sensory analysis. We also thank Chr. Hansen Inc. (Milwaukee, WI) for their donation of starter cultures and coagulants used in this study. The financial support of Dairy Farmers of Wisconsin (Madison, WI) and partial funding of CONICYT (Comisión Nacional de 
Investigación Científica y Tecnológica; Santiago, Chile) to Rodrigo A. Ibáñez was greatly appreciated. The authors have not stated any conflicts of interest.

\section{REFERENCES}

AOAC International. 2000. Official Methods of Analysis. 17th ed. AOAC International, Arlington VA.

Callanan, M. J., and R. P. Ross. 2004. Starter cultures: Genetics. Pages 149-161 in Cheese: Chemistry, Physics and Microbiology. Vol. 1. P. F. Fox and P. L. H. McSweeney, ed. Chapman and Hall, London, UK.

Creamer, L. K., and N. F. Olson. 1982. Rheological evaluation of maturing Cheddar cheese. J. Food Sci. 47:631-636. https://doi.org/ 10.1111/j.1365-2621.1982.tb10138.x.

Fagan, C. C., D. J. O'Callaghan, M. J. Mateo, and P. Dejmek. 2017. The syneresis of rennet-coagulated curd. Pages 145-177 in Cheese: Chemistry, Physics and Microbiology, Volume 1, General Aspects. 4th ed. P. L. H. McSweeney, P. F. Fox, P. D. Cotter, and D. W. Everett, ed. Elsevier, London, UK.

Feeney, E. P., T. P. Guinee, and P. F. Fox. 2002. Effect of pH and calcium concentration on proteolysis in Mozzarella cheese. J. Dairy Sci. 85:1646-1654. https://doi.org/10.3168/jds.S0022 $-0302(02) 74237-9$

Fenelon, M. A., and T. P. Guinee. 2000. Primary proteolysis and textural changes during ripening in Cheddar cheeses manufactured to different fat contents. Int. Dairy J. 10:151-158. https://doi.org/10 .1016/S0958-6946(00)00040-6.

Govindasamy-Lucey, S., J. J. Jaeggi, A. L. Bostley, M. E. Johnson, and J. A. Lucey. 2004. Standardization of milk using cold ultrafiltration retentates for the manufacture of Parmesan cheese. J. Dairy Sci. 87:2789-2799. https://doi.org/10.3168/jds.S0022 -0302(04)73406-2.

Govindasamy-Lucey, S., J. J. Jaeggi, M. E. Johnson, T. Wang, and J. A. Lucey. 2005. Use of cold ultrafiltered retentates for standardization of milks for pizza cheese: Impact on yield and functionality. Int. Dairy J. 15:941-955. https://doi.org/10.1016/j.idairyj.2004.08 .017 .

Govindasamy-Lucey, S., J. J. Jaeggi, C. Martinelli, M. E. Johnson, and J. A. Lucey. 2011. Standardization of milk using cold ultrafiltration retentates for the manufacture of Swiss cheese: Effect of altering coagulation conditions on yield and cheese quality. J. Dairy Sci. 94:2719-2730. https://doi.org/10.3168/jds.2010-3842.

Green, W. C., and K. K. Park. 1980. Comparison of AOAC, microwave and vacuum oven methods for determining total solids in milk. J. Food Prot. 43:782-783. https://doi.org/10.4315/0362-028X-43.10 .782 .

Hassan, A., M. E. Johnson, and J. A. Lucey. 2004. Changes in the proportions of soluble and insoluble calcium during the ripening of Cheddar cheese. J. Dairy Sci. 87:854-862. https://doi.org/10 .3168/jds.S0022-0302(04)73229-4.

Hou, J., J. A. Hannon, P. L. H. McSweeney, T. P. Beresford, and T. P. Guinee. 2014. Effect of curd washing on cheese proteolysis, texture, volatile compounds, and sensory grading in full fat Cheddar cheese. Int. Dairy J. 34:190-198. https://doi.org/10.1016/j.idairyj 2013.08.008.

Ibáñez, R. A., D. S. Waldron, and P. L. H. McSweeney. 2016. Effect of pectin on the composition, microbiology, texture, and functionality of reduced-fat Cheddar cheese. Dairy Sci. Technol. 96:297-316. https://doi.org/10.1007/s13594-015-0265-y.

Johnson, M. E., R. Kapoor, D. J. McMahon, D. R. McCoy, and R. G. Narasimmon. 2009. Reduction of sodium and fat levels in natural and processed cheeses: Scientific and technological aspects. Compr. Rev. Food Sci. Food Saf. 8:252-268. https://doi.org/10.1111/j .1541-4337.2009.00080.x.

Johnson, M. E., and J. A. Lucey. 2006a. Major technological advances and trends in cheese. J. Dairy Sci. 89:1174-1178. https://doi.org/ 10.3168/jds.S0022-0302(06)72186-5.

Johnson, M. E., and J. A. Lucey. 2006b. Calcium: A key factor in controlling cheese functionality. Aust. J. Dairy Technol. 61:147-153.
Johnson, M. E., and N. F. Olson. 1985a. A comparison of available methods for determining salt levels in cheese. J. Dairy Sci. 68:10201024. https://doi.org/10.3168/jds.S0022-0302(85)80924-3.

Johnson, M. E., and N. F. Olson. 1985b. Nonenzymatic browning of Mozzarella cheese. J. Dairy Sci. 68:3143-3147. https://doi.org/10 $.3168 /$ jds.S0022-0302(85)81219-4.

Kuchroo, C. N., and P. F. Fox. 1982. Soluble nitrogen in Cheddar cheese. Milchwissenschaft 37:331-335.

Lawrence, R. C., L. K. Creamer, and J. Gilles. 1987. Texture development during cheese ripening. J. Dairy Sci. 70:1748-1760. https:// doi.org/10.3168/jds.S0022-0302(87)80207-2.

Lawrence, R. C., and T. D. Thomas. 1979. The fermentation of milk by lactic acid bacteria. Page 187 in Microbial Technology: Current State, Future Prospects. A. T. Bull, D. C. Ellwood, and C. Ratledge, ed. Cambridge Univ. Press, London, UK.

Lee, M.-R., M. E. Johnson, S. Govindasamy-Lucey, J. J. Jaeggi, and J. A. Lucey. 2010. Insoluble calcium content and rheological properties of Colby cheese during ripening. J. Dairy Sci. 93:1844-1853. https://doi.org/10.3168/jds.2009-2734.

Lee, M.-R., M. E. Johnson, S. Govindasamy-Lucey, J. J. Jaeggi, and J. A. Lucey. 2011. Effect of different curd-washing methods on the insoluble Ca content and rheological properties of Colby cheese during ripening. J. Dairy Sci. 94:2692-2700. https://doi.org/10 $.3168 /$ jds.2010-3753.

Lee, M.-R., M. E. Johnson, and J. A. Lucey. 2005. Impact of modifications in acid development on the insoluble calcium content and rheological properties of Cheddar cheese. J. Dairy Sci. 88:37983809. https://doi.org/10.3168/jds.S0022-0302(05)73065-4.

Lolkema, H. 1991. Cheese yield used as an instrument for process control-Experience in Friesland, the Netherlands. Pages 156-197 in Factors Affecting the Yield of Cheese. Special Issue No. 9301. International Dairy Federation, Brussels, Belgium.

Lucey, J. A., B. Hauth, C. Gorry, and P. F. Fox. 1993. The acid-base buffering properties of milk. Milchwissenschaft 48:268-272.

Lucey, J. A., M. E. Johnson, and D. S. Horne. 2003. Perspectives on the basis of the rheology and texture properties of cheese. J. Dairy Sci. 86:2725-2743. https://doi.org/10.3168/jds.S0022 -0302(03)73869-7.

Marshall, R. T. 1992. Standard Methods for the Examination of Dairy Products. 16th ed. American Public Health Association, Washington, DC.

McSweeney, P. L. H., and P. F. Fox. 2004. Metabolism of residual lactose and of lactate and citrate. Pages 361-371 in Cheese: Chemistry, Physics and Microbiology, Vol. 1. P. F. Fox and P. L. H. McSweeney, ed. Chapman and Hall, London, UK.

Meilgaard, M. M., G. V. Civille, and B. T. Carr. 1999. Selection and training of panel members. Pages 174-176 in Sensory Evaluation Techniques. CRC Press, Boca Raton, FL.

Møller, K. K., F. P. Rattray, E. Høier, and Y. Ardö. 2012. Manufacture and biochemical characteristics during ripening of Cheddar cheese with variable $\mathrm{NaCl}$ and equal moisture content. Dairy Sci. Technol. 92:515-540. https://doi.org/10.1007/s13594-012-0076-3.

Montgomery, D. C. 2013. Design and Analysis of Experiments. 8th ed. John Wiley \& Sons Inc, Hoboken, NJ.

Moynihan, A. C., S. Govindasamy-Lucey, M. Molitor, J. J. Jaeggi, M. E. Johnson, P. L. H. McSweeney, and J. A. Lucey. 2016. Effect of standardizing the lactose content of cheesemilk on the properties of low-moisture, part-skim Mozzarella cheese. J. Dairy Sci. 99:7791-7802. https://doi.org/10.3168/jds.2016-11215.

Mulvihill, D. M., and P. F. Fox. 1980. Proteolysis of $\alpha_{S_{1}}$-casein by chymosin in dilute $\mathrm{NaCl}$ solutions and in Cheddar cheese. Irish J. Food Sci. Technol. 4:13-23.

O'Mahony, J. A., J. A. Lucey, and P. L. H. McSweeney. 2005. Chymosin-mediated proteolysis, calcium solubilization, and texture development during the ripening of Cheddar cheese. J. Dairy Sci 88:3101-3114. https://doi.org/10.3168/jds.S0022-0302(05)72992 $-1$.

Park, Y. W. 2000. Comparison of mineral and cholesterol composition of different commercial goat milk products manufactured in USA. Small Rumin. Res. 37:115-124. https://doi.org/10.1016/S0921 -4488(99)00144-3. 
Rehman, S., D. Waldron, and P. F. Fox. 2004. Effect of modifying lactose concentration in cheese curd on proteolysis and in quality of Cheddar cheese. Int. Dairy J. 14:591-597. https://doi.org/10 .1016/j.idairyj.2003.11.008.

Singh, T. K., N. D. Young, M. Drake, and K. R. Cadwallader. 2005. Production and sensory characterisation of a bitter peptide form beta-casein. J. Agric. Food Chem. 53:1185-1189. https://doi.org/ 10.1021/jf049058d.

Upreti, P., and L. E. Metzger. 2006. Influence of calcium and phosphorus, lactose, and salt-to-moisture ratio on Cheddar cheese quality: Manufacture and composition. J. Dairy Sci. 89:420-428. https:// doi.org/10.3168/jds.S0022-0302(06)72106-3.

Van den Berg, G., W. C. Meijer, E.-M. Dusterhoft, and G. Smit. 2004. Gouda and related cheeses. Pages 103-140 in Cheese: Chemistry, Physics and Microbiology, Vol. 2. P. F. Fox and P. L. H. McSweeney, ed. Chapman and Hall, London, UK.

Visser, S., G. Hup, F. A. Exterkate, and J. Stadhouders. 1983. Bitter flavour in cheese. 2. Model studies on the formation and degradation of bitter peptides by proteolytic enzymes from calf rennet, starter cells and starter cell fractions. Neth. Milk Dairy J. $37: 169-180$.
Visser, S., and K. J. Slanger. 1977. On the specificity of chymosin (renin) in its action on $\beta$-casein. Neth. Milk Dairy J. 31:16-30.

Watkinson, P., C. Coker, R. Crawford, C. Dodds, K. Johnston, A. McKenna, and N. White. 2001. Effect of cheese pH and ripening time on model cheese textural properties and proteolysis. Int. Dairy J. 11:455-464. https://doi.org/10.1016/S0958-6946(01)00070-X.

Zeppa, G., L. Conterno, and V. Gerbi. 2001. Determination of organic acids, sugars, diacetyl, and acetoin in cheese by high-performance liquid chromatography. J. Agric. Food Chem. 49:2722-2726. https: //doi.org/10.1021/jf0009403.

\section{ORCIDS}

R. A. Ibáñez (ํ) https://orcid.org/0000-0003-2333-3097

S. Govindasamy-Lucey () https://orcid.org/0000-0001-9485-7416

M. E. Johnson (ํ) https://orcid.org/0000-0003-2123-6787

J. A. Lucey @ https://orcid.org/0000-0002-8838-5130 